\title{
Editorial
}

Journal of Innate

Immunity
J Innate Immun 2018;10:83-84

DOI: $10.1159 / 000487341$

Published online: March 6, 2018

\section{Full Complement}

The second issue of the Journal of Innate Immunity in 2018 is another example of the manifold areas covered by the innate immune system. For instance, Irmscher et al. [1] describe a novel mechanism where the plasma enzyme kallikrein cleaves the key complement component C3. The cleavage site is identical to that of $\mathrm{C} 3$ convertase, and generated $\mathrm{C} 3 \mathrm{~b}$ forms $\mathrm{C} 3$ convertases, triggering the $\mathrm{C} 3$ amplification loop. Ultimately, these events merge with the amplification loop of the alternative pathway. This emphasizes the key importance of complement, with several pathways to cause activation, resulting in the subsequent immune responses including the opsonization of bacteria, the promotion of chemotaxis, phagocytosis, and bacterial killing executed by the neutrophils [2-4].

In the airways, immunity is obviously aimed at keeping us healthy, clearing infections, and promoting healing processes [5-10]. However, long-standing and dysregulated inflammation in the airways is a key feature of several states of disease, e.g., in COPD and cystic fibrosis [11-13]. Furthermore, without a preceding chronic airway inflammation, the host response may cause tissue damage $[10,14]$. This may release damage-associated molecular patterns (DAMPs), e.g., extracellular histones, that promote inflammation and aggravate tissue injury [15].

The findings presented in this issue by Ito et al. [16] are highly interesting, showing that Toll-interacting protein (Tollip), a key negative regulator of innate immunity, downregulates IL-13-mediated pulmonary eosinophilia in mice. This points to a potential novel target for dampening inflammation in allergic asthma.

Depriving bacteria of iron with iron-binding proteins or by downregulating access to the iron of the host is an important arm of innate host defense [17]. In their interesting study, Coates et al. [18] show that this is a strategy also utilized by the evolutionarily ancient sea urchin. The sea urchin achieves this via the release of the naphthoquinone pigment echinochrome A from red spherule cells, thereby acting as a primate chelator of iron in the extracellular environment.

Oncolytic viruses are a novel and promising strategy for treating cancer [19]. However, the effects of these viruses on the immune system are not yet fully explored. Tomczyk et al. [20] study the oncolytic vesicular stomatitis virus (VSV), which can be delivered intravenously to target primary and metastatic lesions. They show that VSV infection triggers the differentiation of blood monocytes into immature dendritic cells as well as their apoptosis, the effects of which can have profound immunological consequences and so need to be elucidated further.

Invasive aspergillosis is a major clinical challenge in immunocompromised patients. It is commonly caused by Aspergillus fumigatus whereas A. nidulans is seldom seen; however, in patients suffering from chronic granulomatous disease patients, $A$. nidulans is a frequent cause of invasive aspergillosis. Thus, interactions with the human host defense likely differ between these 2 pathogens [21]. Gresnigt et al. [22] present a study where they show that $A$. nidulans induced a lower oxidative burst but a higher production of cytokines in peripheral blood mononuclear cells. This resulted in a slower rate of killing in the case of A. nidulans when compared to A. fumigatus, demonstrating differences with respect to immune system interactions that can explain selective advantages during the infection of compromised hosts.

Taken together, this issue of the Journal of Innate Immunity presents a broad set of perspectives on innate immunity that we hope makes for enjoyable reading!

Heiko Herwald, Lund

Arne Egesten, Lund 


\section{References}

1 Irmscher S, Döring N, Halder LD, Jo EAH, Kopka I, Dunker C, Jacobsen ID, Luo S, Slevogt H, Lorkowski S, Beyersdorf N, Zipfel PF, Skerka C: Kallikrein cleaves C3 and activates complement. J Innate Immun 2017, DOI: $10.1159 / 000484257$.

2 Trouw LA, Pickering MC, Blom AM: The complement system as a potential therapeutic target in rheumatic disease. Nat Rev Rheumatol 2017;13:538-547.

3 Nauseef WM, Borregaard N: Neutrophils at work. Nat Immunol 2014;15:602-611.

4 Hansen MB, Rasmussen LS, Pilely K, Hellemann D, Hein E, Madsen MB, Hyldegaard O, Garred P: The lectin complement pathway in patients with necrotizing soft tissue infection. J Innate Immun 2016;8:507-516.

5 García-Laorden MI, Stroo I, Blok DC, Florquin S, Medema JP, de Vos AF, van der Poll T: Granzymes A and B regulate the local inflammatory response during Klebsiella pneumoniae pneumonia. J Innate Immun 2016;8: 258-268.

6 Carevic M, Öz H, Fuchs K, Laval J, Schroth C, Frey N, Hector A, Bilich T, Haug M, Schmidt A, Autenrieth SE, Bucher K, Beer-Hammer S, Gaggar A, Kneilling M, Benarafa C, Gao JL, Murphy PM, Schwarz S, Moepps B, Hartl D: CXCR1 regulates pulmonary anti-pseudomonas host defense. J Innate Immun 2016;8: 362-373.

7 Subramanian K, Bergman P, Henriques-Normark B: Vitamin D promotes pneumococcal killing and modulates inflammatory responses in primary human neutrophils. J Innate Immun 2017;9:375-386.

8 Feng J, Cao Z, Wang L, Wan Y, Peng N, Wang Q, Chen X, Zhou Y, Zhu Y: Inducible GBP5 mediates the antiviral response via interferon-related pathways during influenza A virus infection. J Innate Immun 2017;9:419-435.
9 Cohen TS: Role of microRNA in the lung's innate immune response. J Innate Immun 2017;9:243-249.

10 Sabbione F, Keitelman IA, Iula L, Ferrero M, Giordano MN, Baldi P, Rumbo M, Jancic C, Trevani AS: Neutrophil extracellular traps stimulate proinflammatory responses in human airway epithelial cells. J Innate Immun 2017;9:387-402.

11 Yoon CM, Nam M, Oh YM, Dela Cruz CS, Kang MJ: Mitochondrial regulation of inflammasome activation in chronic obstructive pulmonary disease. J Innate Immun 2016; 8:121-128.

12 Amatngalim GD, Schrumpf JA, Henic A, Dronkers E, Verhoosel RM, Ordonez SR, Haagsman HP, Fuentes ME, Sridhar S, Aarbiou J, Janssen RAJ, Lekkerkerker AN, Hiemstra PS: Antibacterial defense of human airway epithelial cells from chronic obstructive pulmonary disease patients induced by acute exposure to nontypeable Haemophilus influenzae: modulation by cigarette smoke. J Innate Immun 2017;9:359-374.

13 Lin CK, Kazmierczak BI: Inflammation: a double-edged sword in the response to Pseudomonas aeruginosa infection. J Innate Immun 2017;9:250-261.

14 Schauer AE, Klassert TE, von Lachner C, Riebold D, Schneeweiß A, Stock M, Müller MM, Hammerschmidt S, Bufler P, Seifert U, Dietert K, Dinarello CA, Nold MF, Gruber AD, Nold-Petry CA, Slevogt H: IL-37 causes excessive inflammation and tissue damage in murine pneumococcal pneumonia. J Innate Immun 2017;9:403-418.
15 Fattahi F, Grailer JJ, Lu H, Dick RS, Parlett M Zetoune FS, Nuñez G, Ward PA: Selective biological responses of phagocytes and lungs to purified histones. J Innate Immun 2017;9: 300-317.

16 Ito Y, Schaefer N, Sanchez A, Francisco D, Alam R, Martin RJ, Ledford JG, Stevenson C, Jiang D, Li L, Kraft M, Chu HW: Toll-interacting protein, Tollip, inhibits IL-13-mediated pulmonary eosinophilic inflammation in mice. J Innate Immun 2018, DOI: 10.1159/ 000485850 .

17 Armitage AE, Lim PJ, Frost JN, Pasricha SR, Soilleux EJ, Evans E, Morovat A, Santos A, Diaz R, Biggs D, Davies B, Gileadi U, Robbins PA, Lakhal-Littleton S, Drakesmith H: Induced disruption of the iron-regulatory hormone hepcidin inhibits acute inflammatory hypoferraemia. J Innate Immun 2016;8:517528.

18 Coates CJ, McCulloch C, Betts J, Whalley T: Echinochrome A release by red spherule cells is an iron-withholding strategy of sea urchin innate immunity. J Innate Immun 2017, DOI: 10.1159/000484722.

19 Lemay CG, Keller BA, Edge RE, Abei M, Bell JC: Oncolytic viruses: the best is yet to come. Curr Cancer Drug Targets 2018;18:109-123.

20 Tomczyk T, Wróbel G, Chaber R, Siemieniec I, Piasecki E, Krzystek-Korpacka M, Orzechowska BU: Immune consequences of in vitro infection of human peripheral blood leukocytes with vesicular stomatitis virus. J Innate Immun 2018, DOI: 10.1159/ 000485143

21 Garth JM, Steele C: Innate lung defense during invasive aspergillosis: new mechanisms. J Innate Immun 2017;9:271-280.

22 Gresnigt MS, Becker KL, Leenders F, Alonso MF, Wang X, Meis JF, Bain JM, Erwig LP, van de Veerdonk FL: Differential kinetics of $A s$ pergillus nidulans and Aspergillus fumigatus phagocytosis. J Innate Immun 2017, DOI: $10.1159 / 000484562$. 